\title{
Investigation of the apoptotic way induced by digallic acid in human lymphoblastoid TK6 cells
}

\author{
Wissem Bhouri ${ }^{1,2}$, Jihed Boubaker ${ }^{1,2}$, Ines Skandrani ${ }^{1,2}$, Kamel Ghedira $^{2,3^{*}}$ and Leila Chekir Ghedira ${ }^{1,2,3^{*}}$
}

\begin{abstract}
Background: The digallic acid (DGA) purified from Pistacia lentiscus. L fruits was investigated for its antiproliferative and apoptotic activities on human lymphoblastoid TK6 cells.

Methods: We attempt to characterize the apoptotic pathway activated by DGA. Apoptosis was detected by DNA fragmentation, PARP cleavage and by evaluating caspase activities.

Results: The inhibition of lymphoblastoid cell proliferation was noted from $8.5 \mu \mathrm{g} / \mathrm{ml}$ of DGA. The induction of apoptosis was confirmed by DNA fragmentation and PARP cleavage. We have demonstrated that DGA induces apoptosis by activating the caspase-8 extrinsic pathway. Caspase-3 was also activated in a dose dependent manner.

Conclusion: In summary, DGA exhibited an apoptosis inductor effect in TK6 cells revealing thus its potential as a cancer-preventive agent.
\end{abstract}

Keywords: Caspase activity, DNA fragmentation, Digallic acid, PARP

\section{Background}

Polyphenols were described to be beneficial against human diseases such as cancer and metastasis [1,2]. It has been shown, in both in vitro test and small animal model study, that polyphenols induce responses consistent with the protective effects of diets rich in fruits and vegetables against degenerative conditions such as cardiovascular disease and carcinogenesis [3,4]. Furthermore, they can be obtained without prescriptions. For example, fresh green tea contains large amounts of catechin polyphenol, while flavonoids resveratrol and quercetin are important in grapes, red wine, and other food products [5]. Epidemiologic studies suggest that diet can affect the risk for cancer and, particularly a diet rich in vegetables reduces this risk [6,7]. Apoptosis, or programmed cell death, is an important physiologic process in the normal development [8], and induction of apoptosis is a highly desirable mode as a therapeutic strategy for cancer control $[9,10]$. The major challenge in treating

\footnotetext{
*Correspondence: kamel.ghedira@gmail.com; leila.chekir@fmdm.rnu.tn Unité de pharmacognosie 99/UR/07, Faculté de pharmacie Monastir, Rue Avicenne, Monastir 5000, Tunisia

'Laboratoire de biologie Cellulaire et Moléculaire, Faculté de Medecine Dentaire Monastir, Rue Avicenne, Monastir 5000, Tunisia

Full list of author information is available at the end of the article
}

cancer is that many tumor cells carry mutations in key apoptotic genes such as p53, BCL family protein, or those affecting caspase signaling [11]. The BCL-2 family determines the life-or-death of a cell by controlling the release of mitochondrial apoptogenic factors associated with death proteases called caspases which are considered as a central player for the apoptotic process and cascade of proteolytic cleavage events [12]. In addition to its importance in the treatment of cancer, caspasedependent processes have also been demonstrated to play an essential role in mediating cell death [13].

Caspase-dependent processes are associated with two pathways of anti-cancer drug-induced apoptosis, death receptor-dependent and mitochondria-dependent pathways [14]. The death receptor apoptosis pathway or the extrinsic pathway had been thought to involve only the caspase cascade in which caspase- 8 activated the downstream effector caspases, such as caspase- 3 and as such mitochondria pathway was not considered to be involved.

However, when it was found that caspase-8 could cleave Bid and the truncated Bid could then translocate to the mitochondria, it became clear that mitochondriainitiated apoptosis pathway (the intrinsic pathway) could also play a role in the death receptor-initiated apoptosis $[15,16,17]$. 
Death receptor activation pathway is mediated with a death-inducing signaling complex, which is made of a Fas-associated death domain and a procaspase-8, activating Caspase-8 [18]. Caspase-8 directly activates Caspase3 , leading to apoptosis.

Although many studies on the anti-cancer mechanisms of polyphenols have been reported, anti-cancer mechanism of digallic acid mediated caspases pathways have not been fully studied.

In the present study, the apoptotic effects of digallic acid (DGA), from Pistacia lentiscus. L fruits, on human lymphoblastoid cells TK6 were examined to determine the apoptotic pathway.

\section{Material and methods \\ Chemicals}

Dimethylsulfoxide (DMSO) was purchased from Sigma (St. Louis, MO, USA), RPMI-1640 Glutamax, foetal bovine serum and gentamicin were bought from GIBCO BRL Life technologies (Grand Island, NY, USA). The proteinase $\mathrm{K}$, the ethylene diamine tetraacetic (EDTA), the sodium dodecyl sulfate (SDS), RNase A and MTT (3(4,5-dimethylthiazol-2-yl)-2,5-diphenyltetrazolium bromide) were obtained from Sigma Aldrich Co (St. Louis, MO, USA). Acrylamide and bisacrylamide were purchased from (Madison,WI,USA), Ethidium bromide (EtBr) and Bromophenol blue were purchased from Merck (Darmstadt, FR, Germany). Agarose and Ployvinylidene difluoride (PVDF) membranes were obtained from Invitrogen, life technologies (UK). The monoclonal antibody i.e. anti poly ADP-ribose polymerase (anti-PARP) and the goat anti mouse alkaline phosphtase conjugated antibody were purchased from (St,Louis, Missouri, USA). The 5-Bromo-4Chloro-3 Indolyl Phosphate (BCIP)/Nitro Bleu Tetrazolium (NBT) and Tween 20 were purchased from promega (Madison, WI, USA). Caspase-3 and caspase-8 colorimetric assay kits were obtained from Sigma RBI (St Louis,MO,USA).

\section{Extraction method}

The powdered fruits of Pistacia lentiscus were extracted with boiling water for $15-20 \mathrm{~min}$. After filtration, the extract was lyophilized leading to an aqueous one. The residue was suspended in water and successively portioned between water and chloroform, ethyl acetate and 1-butanol. Each liquid-liquid extraction was carried out three times (water: organic solvent $=1: 1 \mathrm{v} / \mathrm{v}$ ). The solvents of the obtained sub-extracts were evaporated under vacuum to dryness. The ethyl acetate soluble fraction ( $2 \mathrm{~g}$ ) was fractionated over silica gel column eluted with $\mathrm{CH}_{2} \mathrm{Cl}_{2}-\mathrm{MeOH}$ gradually increasing the $\mathrm{MeOH}$ content and three fractions were collected. Fraction 1 was rechromatographed over Sephadex LH20 eluted with $100 \% \mathrm{MeOH}$ and nine sub-fractions were obtained.
Sub-fraction 7 was further purified over Sephadex LH20 column eluted with $\mathrm{MeOH}-\mathrm{H}_{2} \mathrm{O}$ (9:1) and nine subfractions were obtained. Sub-fraction 6 was purified by passage through (C18) disposable extraction column eluted with methanol and water content to afford $24.5 \mathrm{mg}$ of digallic acid (DGA). Figure 1 [19].

\section{Nuclear magnetic resonance (NMR)}

NMR spectroscopy experiments on the compounds were performed on a Bruker_Avance 400 at $400 \mathrm{MHz}$ (for ${ }^{1} \mathrm{H}$ $\mathrm{NMR}$ ) and $100 \mathrm{MHz}$ (for ${ }^{13} \mathrm{C} \mathrm{NMR}$ ) with CD3OD as solvent. FAB-MS (negative- ion mode, glycerol matrix) was recorded on an R210C (VG Instruments, Altrincham, UK) spectrometer equipped with an IPC (P2A) MSCAN WALLIS computer system. COSY, HMQC, and HMBC spectra were obtained using the usual pulse sequences.

\section{Cell lines, cell culture and chemicals}

Human lymphoblastoid cell line TK6 (Kindely provided by Pr. Pierre Biscoff centre Paul Strauss Strasbourg. France) expresses wild-type p53, and is thus p53 proficient. Cells were cultivated in RPMI-1640 glutamax supplemented with $10 \%(\mathrm{v} / \mathrm{v})$ foetal bovine serum, $1 \mathrm{mM}$ sodium pyruvate, $1 \mathrm{mM}$ non-essential amino acids, $50 \mu \mathrm{g} / \mathrm{ml}$ gentamicin at $37^{\circ} \mathrm{C}$ in humidified atmosphere with $5 \% \mathrm{CO}_{2}$. The experiments were performed after approximately two passages to limit chromosome instability due to culture maintenance.

\section{Cell proliferation assay}

The evaluation of antiproliferative activity is based on the reduction of MTT (3-(4,5-dimethylthiazol-2-yl)-2,5diphenyltetrazolium bromide) by the mitochondrial dehydrogenase of viable cells to give a blue formazan product which can be measured spectrophotometrically. The MTT colorimetric assay was performed in 96-well plates $[20,21]$. TK6 cells were seeded in 96 wells plate at a concentration of $5.10^{4}$ cells/well and incubated during $24 \mathrm{~h}$ at $37^{\circ} \mathrm{C}$. After treatment with various concentrations

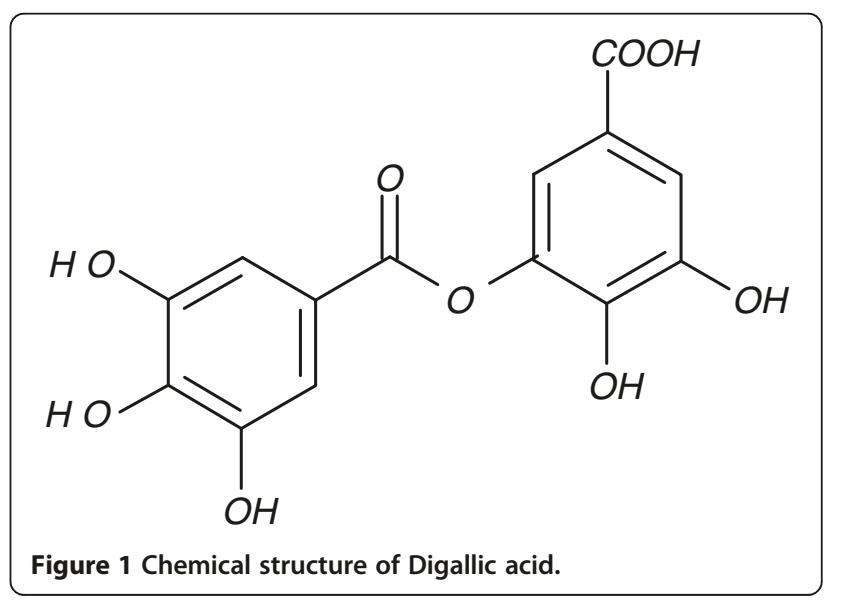


of the tested compound (10, 20, 50, 100 and $200 \mu \mathrm{g} / \mathrm{ml}$ ), the cells were incubated for an additional $48 \mathrm{~h}$ at $37^{\circ} \mathrm{C}$. After incubation, the medium was removed, and cells in each well were incubated with $50 \mu \mathrm{l}$ of MTT solution $(5 \mathrm{mg} / \mathrm{ml})$ for $4 \mathrm{~h}$ at $37^{\circ} \mathrm{C}$. MTT solution was then discarded, and $50 \mu \mathrm{l}$ of DMSO were added to dissolve insoluble formazan crystal. Optical density was measured at $540 \mathrm{~nm}$. Data were obtained from triplicate wells. The proliferation inhibitory effect was determined with regard to the negative control (vehicle treated cells).

\section{DNA fragmentation analysis}

DNA fragmentation was analysed by agarose gel electrophoresis as described by Wang et al. (2002). TK6 cells $\left(1.510^{6}\right.$ cells $\left./ \mathrm{ml}\right)$ were exposed to tested compound at a concentrations of $2.5,5$ and $10 \mu \mathrm{g} / \mathrm{ml}$ for 24 and $48 \mathrm{~h}$ and harvested by centrifugation. Control cells were also treated with $0.5 \%$ of DMSO.

Cell pellets were resuspended in $200 \mu \mathrm{l}$ of lysis buffer (50 mM Tris-HCl, pH 8.0, 10 mM EDTA, 0.5\% N-Lauroyl Sarcosine Sodium Salt) at room temperature for $1 \mathrm{~h}$, then centrifuged at $12000 \mathrm{~g}$ for $20 \mathrm{~min}$ at $4 \mathrm{C}$. The supernatant was incubated overnight at $56^{\circ} \mathrm{C}$ with $250 \mu \mathrm{g} / \mathrm{ml}$ proteinase $\mathrm{K}$. Cell lysates were then treated with $2 \mathrm{mg} / \mathrm{ml}$ RNase $\mathrm{A}$ and incubated at $56 \mathrm{C}$ for $2 \mathrm{~h}$. DNA was extracted with chloroform/phenol/isoamyl alcohol (24/25/1, v/v/v) and precipitated from the aqueous phase by centrifugation at $14000 \mathrm{~g}$ for $30 \mathrm{~min}$ at $0^{\circ} \mathrm{C}$. The solution recuperated was transferred to a $1.5 \%$ agarose gel and electrophoresis was carried out at $67 \mathrm{~V}$ for $3 / 4$ h with TAE buffer (Tris $2 \mathrm{M}$, sodium acetate $1 \mathrm{M}$, EDTA $50 \mathrm{mM}$ ) as the running buffer. DNA in the gel was visualized with ethidium bromide $(0.5 \mu \mathrm{g} / \mathrm{ml})$ under UV light [22].

\section{Western blot analysis}

Cells, treated with different concentrations of DGA (2.5, 5 and $10 \mu \mathrm{g} / \mathrm{ml}$ ) for 6,24 and $48 \mathrm{~h}$ as well as control cells treated with $0.5 \%$ DMSO, were lysed with a lysis buffer $(62.5 \mathrm{mM}$ Tris $\mathrm{HCl}$ and $6 \mathrm{M}$ urea, $\mathrm{pH}=6.8)$. Protein concentrations were determined in cell lysates using the Bradford method [23]. Equal amounts of proteins were separated on sodium dodecyl sulfate polyacrylamide gel electrophoresis (SDS-PAGE), and transferred onto PVDF membrane, which was then blocked with 5\% of non-fat milk in $0.1 \%$ Tween 20-Phosphate buffer salin (PBST) overnight at $4^{\circ} \mathrm{C}$. Membranes were then incubated with a primary antibody anti-PARP at a 1:100 dilution for $2 \mathrm{~h}$ at room temperature. The membrane was then washed and incubated with a goat anti-mouse alkaline phosphatase-conjugated antibody at 1:7500 dilution for $1 \mathrm{~h}$. Next, the membrane was washed and the chromogenic substrate BCIP/NBT was added to localise antibody binding proteins.

\section{The study of caspase- 3 and caspase- 8 activities}

Cells were cultured $\left(10^{6}\right.$ cells $\left./ \mathrm{ml}\right)$ in $25 \mathrm{~cm}^{2}$ flasks for $24 \mathrm{~h}$ in the absence or the presence of 2.5, 5 and $10 \mu \mathrm{g} /$ $\mathrm{ml}$ of DGA at $37^{\circ} \mathrm{C}$. Controls were performed at the same time with $0.5 \%$ DMSO. Cells were harvested and centrifuged at $600 \times g$ and the pellets were washed with PBS, then incubated in ice cold lysis buffer for $15 \mathrm{~min}$, then centrifuged at $16000 \times g$ for $20 \mathrm{~min}$. Supernatants (cell extracts eventually containing caspase- 3 and caspase-8) were retrieved and aliquots corresponding to $50 \mu \mathrm{g}$ total protein were incubated along with acetylated tetrapeptide (Ac-DEVD) substrate labelled with the chromophore $p$-nitroaniline (pNA) in the presence of caspase buffer in a 96-well flat bottomed microplate. In the presence of active caspase- 3 and caspase- 8 , cleavage and release of pNA from the substrate occurs. Free pNA produces a yellow color, detected spectrophotometrically at $405 \mathrm{~nm}$. Lecture of absorbance at $405 \mathrm{~nm}$ was done against a blank performed at the same time and containing assay buffer and substrate but without cell lysate. A standard curve was realized in order to determine the correspondence between absorbance and pNA concentration, then the results were expressed as caspase- 3 and caspase- 8 specific activity ( $\mu \mathrm{mol}$ pNA per $\mathrm{min} / \mathrm{ml}$ protein) calculated as indicated by the manufacturers.

\section{Statistical analysis}

All tests were carried out in triplicate and the results were presented as means $\pm \mathrm{SD}$. The data were tested for statistical differences by one-way ANOVA followed by Dunett test using STATISTICA (Version 6.0, Statsoft, Inc.) to compare data of control (untreated cells) to those of cells treated by different extracts. Statistical differences were determined at the $P<0.05$.

\section{Results}

\section{Evaluation of antiproliferative activity}

Human lymphoblastoid TK6 cells were treated with the compound isolated from $P$. lentiscus fruits, for $48 \mathrm{~h}$ at $37^{\circ} \mathrm{C}$. Antiproliferative activity of the compound was evaluated by the MTT assay. The results, summarized in Figure 2, showed that the DAG inhibited cell proliferation. The $\mathrm{IC}_{50}$ value was $8.5 \mu \mathrm{g} / \mathrm{ml}$.

\section{Induction of apoptotic DNA fragmentation by DGA}

The fragmentation of TK6 cell DNA was detected on a $1.5 \%$ agarose gel electrophoresis after exposing $1.5 \times 10^{6}$ cells to $0,2.5,5$ and $10 \mu \mathrm{g} / \mathrm{ml}$ of DGA during $24 \mathrm{~h}$ and $48 \mathrm{~h}$. Examination of cell DNA electrophoretic profiles revealed a ladder formation, which is characteristic of apoptosis (Figure 3). At exposure to $2.5-10 \mu \mathrm{g} / \mathrm{ml}$ with DGA during $24 \mathrm{~h}$ and at exposure to $2.5-10 \mu \mathrm{g} / \mathrm{ml}$ during $48 \mathrm{~h}$, a ladder DNA profile was clearly observed in TK6 cells. Whereas control cells did not provide any ladder 


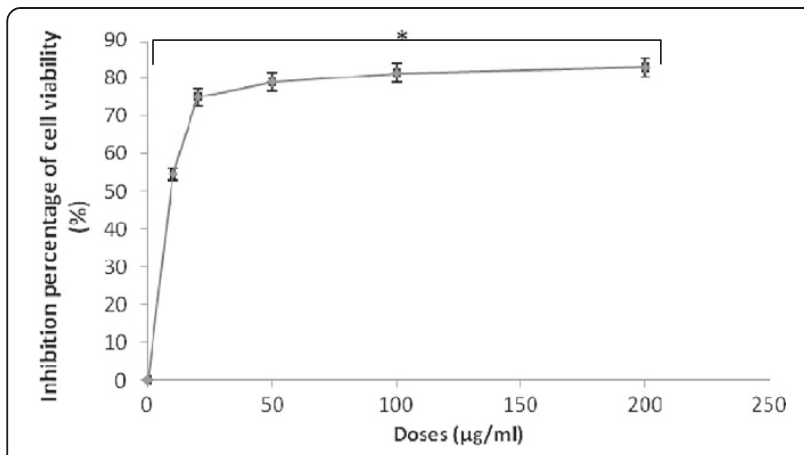

Figure $\mathbf{2}$ Inhibitory effect of digallic acid on the viability of TK6 cells. * Significant from control $(p<0.05)$.

DNA profile. We deduce that DGA compound from Pistascia Lentiscus fruits induces apoptosis in TK6 cells.

\section{Effect of digallic acid on the proteolysis of PARP}

DNA fragmentation is often associated with the activation of a family of cysteine proteases, the caspases. Caspase 3 , in particular, seems to play an important role in several models of apoptosis [10,23]. To confirm the apoptotic process of the observed DNA fragmentation, we also investigated, the enzymatic activation of apoptotic proteins by measuring the cleavage of PARP, which is a caspase- 3 substrate.

As shown in Figure 4, when cells were treated with $P$. lentiscus compound, an increase in the formation of $85 \mathrm{kDa}$ fragment and a decrease or a total disappearence

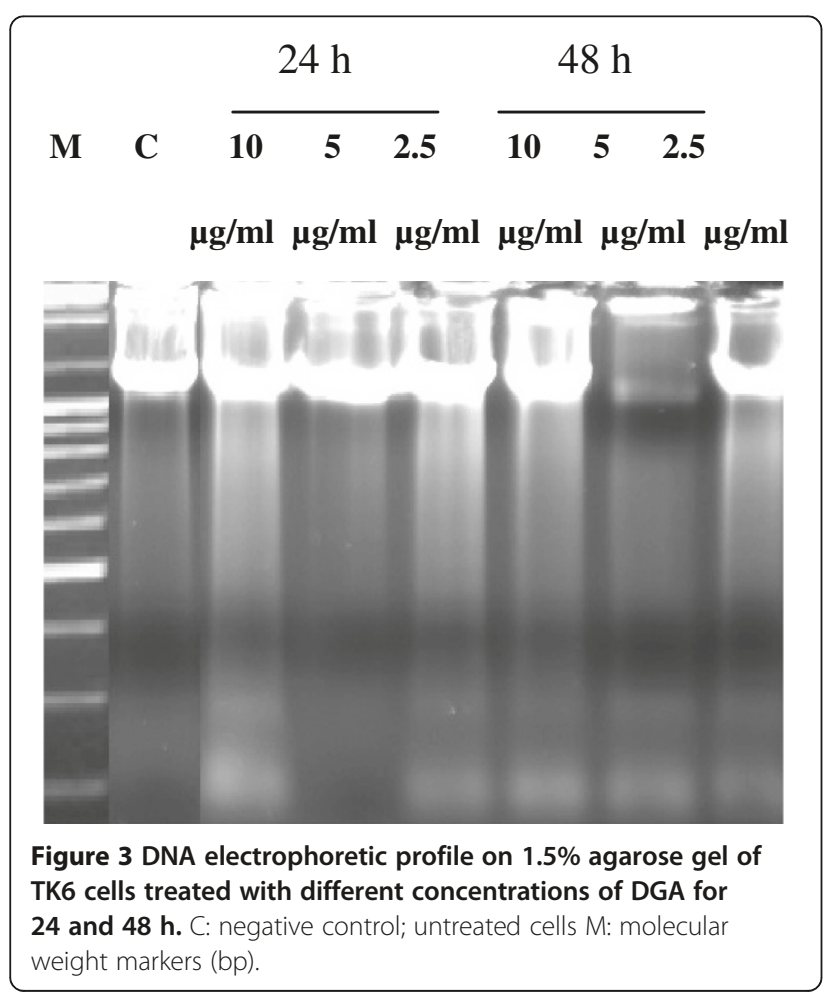

of the $116 \mathrm{kDa}$ band were observed. The addition of DGA induces cleavage of $116 \mathrm{kDa}$ PARP into fragments of 85 and $31 \mathrm{kDa}$ in an inversely concentration- dependant manner, at the three tested time incubation.

\section{Caspase- 3 and caspase- 8 activation assay}

The cellular pathway of DGA induced cell death was examined by assessing caspase- 3 and caspase- 8 activities. Following, $24 \mathrm{~h}$ and $48 \mathrm{~h}$ treatment of TK6 cells with various concentrations of DGA, caspase- 3 and caspase- 8 activities were measured and compared with control cells. As shown in Figure 5 and Figure 6, TK6 cells treated with DGA for 24 and $48 \mathrm{~h}$, showed a significant concentrationdepending increase of caspase- 3 and caspase- 8 activities.

At the highest concentration $10 \mu \mathrm{g} / \mathrm{ml}$, the values of caspases 3 activity were 2.2 and $4.9 \mu \mathrm{mol} \mathrm{pNA} / \mathrm{min} / \mathrm{ml}$ at respectively $24 \mathrm{~h}$ and $48 \mathrm{~h}$ incubation. At this concentration the compound showed a significant induction of caspase 3 activity compared to untreated cells $(2 \mu \mathrm{mol}$ $\mathrm{pNA} / \mathrm{min} / \mathrm{ml}$ ). In the same way, DGA showed the highest caspase 8 induction activity at the same concentration $(10 \mu \mathrm{g} / \mathrm{ml})$ after $24 \mathrm{~h}$ of treatment with a value of $3.33 \mathrm{pNA} / \mathrm{min} / \mathrm{ml}$. These results suggest that apoptosis induced by the tested polyphenol may occur through the activation of common executors of apoptosis, such as caspase- 3 through the activation of caspase-8.

\section{Discussion}

In recent years, the role of lifestyle and dietary behavior in reducing cancer risk has drawn widespread attention based on the geographic differences in cancer incidence and mortality. Natural compounds have been adopted increasingly in the field of chemoprevention, as well as the synthetic chemicals, that have been identified for inhibiting or reversing carcinogenesis [24,25]. Cancer preventive phytochemicals have been shown to suppress or block cancer progression by a variety of mechanisms including; acting as anti-proliferative agents or as antioxidants [26]. On the basis of this regard, extensive investigations on phenolic acids have shown promising results against different cancers including human leukemia, gastric cancer, colon cancer, etc. [27,28].

Digallic acid, is a polyhydroxyphenolic compound, widely distributed in various plants and fruits, such as Pistacia lentiscus and Myrtus communis from Tunisian flore $[19,29]$, green tea, apple peels, grapes, strawberries, lemons and in red and white wine. Our previous studies established that digallic acid showed significant antioxidant and antimutagenic activities [16].

In this study, we found that DGA inhibited cell growth of human lymphoblastoid cell lines with an $\mathrm{IC}_{50}$ value of $8.5 \mu \mathrm{g} / \mathrm{ml}$ and that cell death occurs by apoptosis as shown by oligonucleosomal DNA cleavage ("DNA ladder") (Figure 3). 

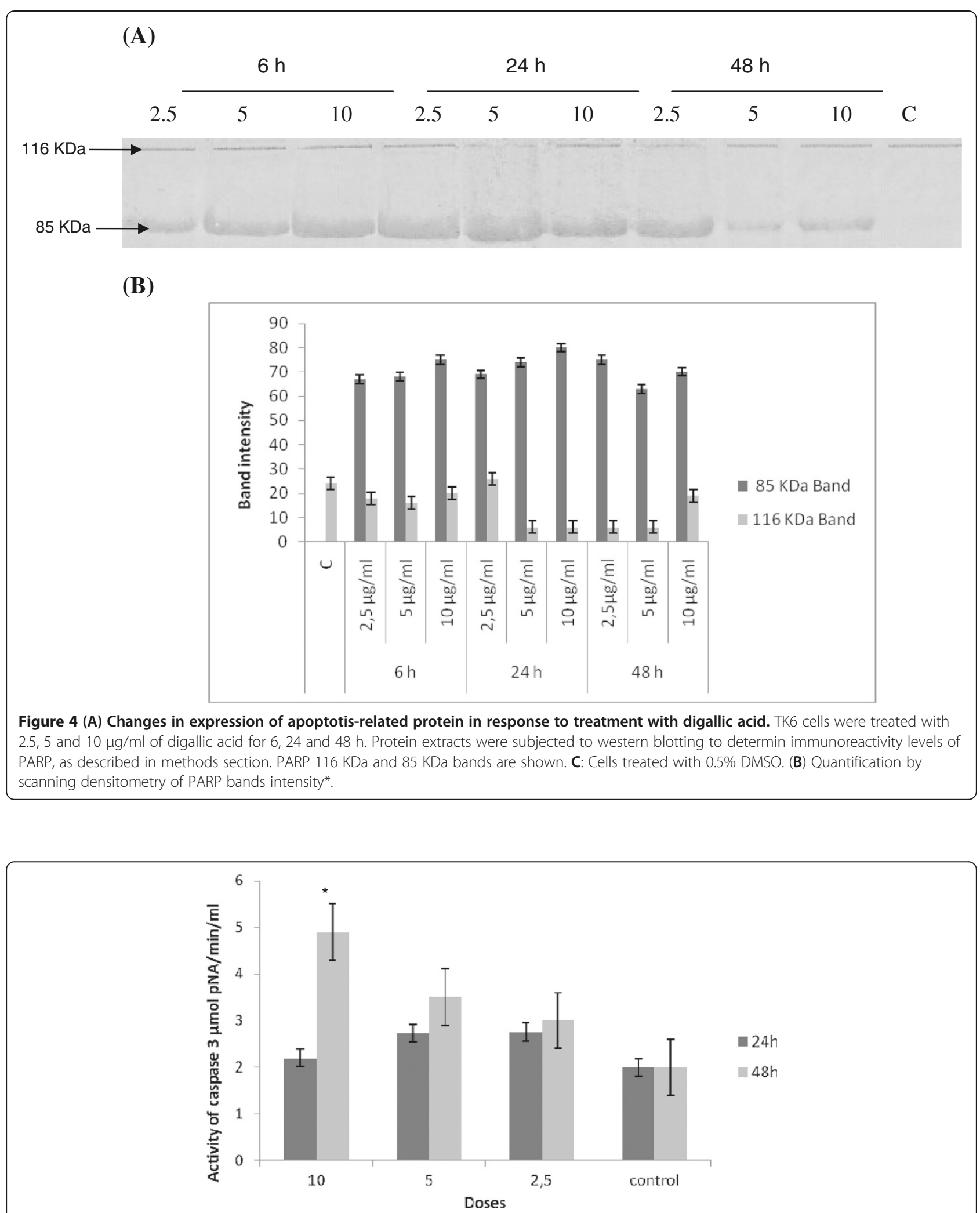

Figure 5 Effect of digallic acid (DGA) on caspase-3 activity in TK6 cells. Lysates prepared from cells treated with the digallic acid for $24 \mathrm{~h}$ and $48 \mathrm{~h}$ were assayed for in vitro caspase-3 activity. The rate of cleavage of the caspase substrate DEVD-pNA was measured at $405 \mathrm{~nm}$. The results are presented as the mean \pm SD. The experiments were done in triplicate. $\left(^{*}\right) p<0.05$ means a significant difference between the untreated and treated cells. Control: cells were treated by the vehicle only*. 


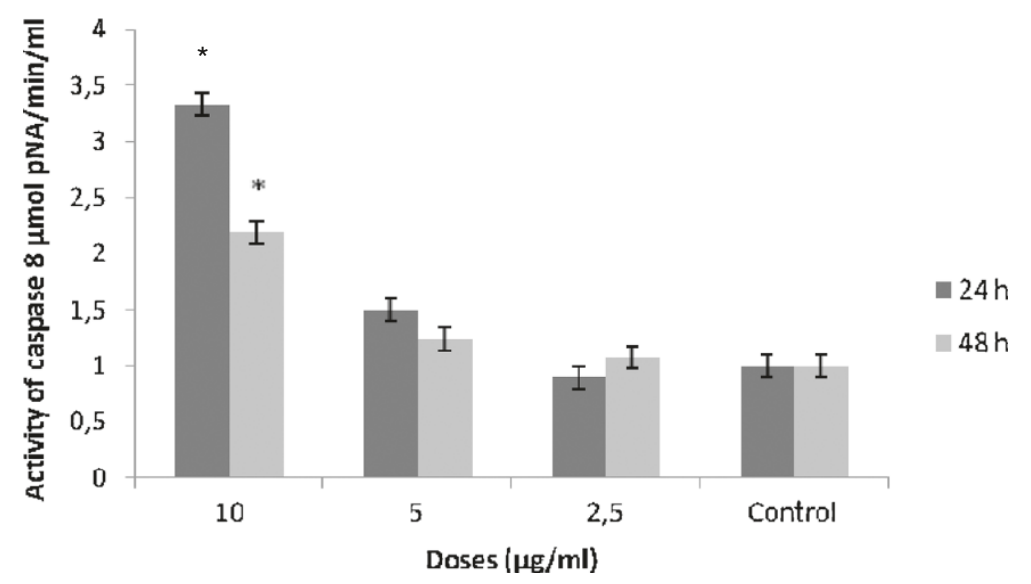

Figure 6 Effect of digallic acid (DGA) on caspase-8 activity in TK6 cells. Lysates prepared from cells treated with the digallic acid for $24 \mathrm{~h}$ and $48 \mathrm{~h}$ were assayed for in vitro caspase-8 activity. The rate of cleavage of the caspase substrate DEVD-pNA was measured at $405 \mathrm{~nm}$. The results are presented as the mean \pm SD. The experiments were done in triplicate. $\left(^{*}\right) p<0.05$ means a significant difference between the untreated and treated cells. Control: cells were treated by the vehicle only.

Furthermore, Isuzugawa et al. (2001) and Inoue et al. (1995) have demonstrated that GA selectively induces cancer cell death by apoptosis; however, gallic acid shows no cytotoxicity against normal cells [30,31].

Apoptosis produced the typical pattern of apoptotic PARP cleavage: a catalytically active band of intact PARP at $116 \mathrm{kDa}$, and an active band at $85 \mathrm{kDa}$ corresponding to the apoptotic cleavage product of PARP. PARP is proteolytically cleaved during apoptosis by caspase-3 [32] which reduces PARP's enzymatic activity [33], thereby inhibiting DNA repair. As shown In Figure 4 DGA- treated TK6 cells show a dose-dependent increase in the cleavage of PARP $(85 \mathrm{kDa})$ which might indicate a breakdown in the DNA repair function.

Indeed, Caspases are synthesized as inactive proenzymes, and their activation during apoptosis results in cleavage at specific aspartate cleavage sites [34]. The downstream signals during apoptosis are transmitted via caspases. Upon conversion from pro- to active forms, caspases mediate the cleavage of PARP, followed by DNA fragmentation. The DNase responsible for the fragmentation is reportedly activated directly by caspase$3[33,34]$. Caspase-3 is one of the key executioners of apoptosis, being responsible either partially or totally for the proteolytic cleavage of many key proteins, such as the nuclear enzyme PARP. Thus, PARP is known to be cleaved in the execution phase of apoptosis.

In the present study, we showed that DGA induced the activation of caspase- 3 in a dose-dependent manner (Figure 5) leading to the cleavage of PARP. This finding indicates that activation of the caspase- 3 pathway may mediate the proapoptotic activity of the tested compound.

Caspases- 8 is synthesized as inactive proenzymes and becomes activated either by oligomerization in a large multimeric complex, or alternatively via proteolytic cleavage, which applies for effector caspases such as caspase-3 [35]. Once activated, they cleave various substrates in the cytoplasm or nucleus causing characteristic morphological features of apoptotic cell death [34]. In the extrinsic apoptosis pathway, stimulation of death receptors of the tumor necrosis factor (TNF) receptor superfamily, e.g. CD95 (APO-1/Fas) or TRAIL receptors, results in activation of the initiator caspase-8, which in turn can directly cleave downstream effector caspases such as caspase-3 [35].

Our result demonstrates that caspase- 8 was activated by DGA in a dose and time depending manner.

According to Chen et al. (1999) [36] and Liang et al. (1999) [37] a pure compound which has two gallic acid moieties, exhibited the strongest anti-proliferative activity on tumor cells by report to a compound which has no gallic acid moiety $[36,37]$. This is in accordance with our result as we obtained a high cytotoxicity against TK6 cells, in the presence of DGA.

Our results revealed the importance of galloyl moieties in inducing apoptosis.

This finding is in accordance with those reported by Pan et al. (1999) who demonstrates that a compound isolated from hydrolyzed tannin, which has five gallic acids, was the most potent apoptosis inducer among tested polyphenols.

According to his study he concludes that gallic acid moieties are important for the exhibited apoptosisinducing potency of these polyphenols [38].

Besides, Haslam et al. (1996) showed that the molecular size of the polyphenol is important; in the galloyl series, the efficacy of binding increases as the number of galloyl groups increases in the order of: tri tetra penta [39]. Moreover, Sakagami et al. (1995) reported a high 
induction of DNA fragmentation in the presence of gallic acid a component unit of tannin [40].

\section{Abbreviations}

DGA: Digallic acid; DMSO: Dimethylsulfoxide; MTT: 3-(4,5-dimethylthiazol-2yl)-2,5-diphenyltetrazolium bromide; PARP: Poly (ADP-ribose) polymerase.

\section{Competing interests}

The authors declare that they have no competing interests.

\section{Authors' contributions}

BW: Was responsible for the conception and design, testing and data acquisition, analysis and data interpretation and drafted the manuscript. BJ: made contribution to the study of caspase activities. SI: made contribution to cell culture and the study of the cytotoxicity and the DNA fragmentation GK: made substantial contribution to conception and revised it critically for Important intellectual content. CGL:made substantial contribution to conception and revised it critically for important intellectual content. All authors read and approved the final manuscript.

\section{Acknowledgments}

The authors acknowledge the « Ministère Tunisien de l'Enseignement Supérieur, de la Recherche Scientifique » and the «Ministère Français des Affaires Etrangères (Action Intégrée de Coopération Inter Universitaire Franco-Tunisienne, CMCU 07 G0836 PAR) », for the financial support of this study, and also thank Ms. Imen Ghadhab (Pr. of English at the Faculty of Dental Medicine, Tunisia) for English editing.

\section{Author details}

'Laboratoire de biologie Cellulaire et Moléculaire, Faculté de Medecine

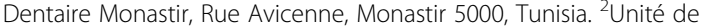
pharmacognosie 99/UR/07, Faculté de pharmacie Monastir, Rue Avicenne, Monastir 5000, Tunisia. ${ }^{3}$ Faculty of Dental Medicine, Rue Avicenne, Monastir 5019, Tunisia.

Received: 15 November 2011 Accepted: 29 May 2012

Published: 11 June 2012

\section{References}

1. Yang CS, Wang ZY: Tea and cancer. J Natl Cancer Inst 1993, 85:1038-1049.

2. Stroner GD, Mukhtar H: Polyphenols as cancer chemopreventive agents. J Cell Biochem 1995, 22:169-180.

3. Manach C, Mazur A, Scalbert A: Polyphenols and prevention of cardiovascular diseases. Curr Opin Lipidol 2005, 16:77-84.

4. Chung FL, Schwartz J, Herzog CR, Yang YM: Tea and cancer prevention: studies in animals and humans. J Nutr 2003, 13:3268-3274.

5. Weisburger $\mathrm{JH}$, Chung FL: Mechanisms of chronic disease causation by prevention by tea polyphenol. Food Chem Toxicol 2002, 40:1145-1154.

6. Block G, Patterson B, Subar A: Fruit, vegetables, and cancer prevention: a review of the epidemiological evidence. Nutr Cancer 1992, 18:1-29.

7. Terry P, Giovannucci E, Michels KB, Bergkvist L, Hansen H, Holmberg L, Wolk A: Fruit, vegetables, dietary fiber and risk of colorectal cancer. J Nat/ Cancer Inst 2001, 93:525-533.

8. Hong MY, Chapkin RS, Davidson LA, Turner ND, Morris JS, Carroll RJ, Lupton JR: Fish oil enhances targeted apoptosis during colon tumor initiation in part by downregulating Bcl-2. Nut and Cancer 2003, 46:44-51.

9. Koo HN, Jeong $\mathrm{HJ}$, Hong $\mathrm{SH}$, Choi JH, An NH, Kim HM: High molecular weight water-soluble chitosan protects against apoptosis induced by serum starvation in human astrocytes. J Nutr Biochem 2002, 13:245-249.

10. Thompson CB: Apoptosis in the pathogenesis and treatment of disease. Science 1995, 267:1456-1462.

11. Hollstein M, Rice K, Greenblatt MS, Soussi T, Fuchs R, Sorlie T, Hovig E, Smith-Sorensen B, Montesano R, Harris CC: Database of p53 gene somatic mutations in human tumors and cell lines. Nucleic Acids Res 1994, 22:3551-3555.

12. Oltvai ZN, Milliman CL, Korsmeyer SJ: BCl-2 heterodimerizes in vivo with a conserved homolog, Bax, that accelerates programmed cell death. Cell 1993, 74:609-619.

13. Yu SW, Wang H, Dawson TM, Dawson VL: Poly(ADPribose) polymerase-1 and apoptosis inducing factor in neurotoxicity. Neurobiol Dis 2003, 14:303-317.
14. Debatin KM: Apoptosis pathways in cancer and cancer therapy. Cancer Immunol Immunoth 2004, 53:153-159.

15. Li H, Zhu H, Xu C, Yuan J: Cleavage of BID by Caspase 8 Mediates the Mitochondrial Damage in the Fas Pathway of Apoptosis. Cell press 1998, 94:491-501.

16. Luo X, Budihardjo I, Zou H, Slaughter C, Wang X: Bid, a Bcl2 Interacting Protein, Mediates Cytochrome $c$ Release from Mitochondria in Response to Activation of Cell Surface Death Receptors. Cell press 1998, 94:481-490.

17. Gross $\mathrm{A}, \mathrm{M}$. McDonnell J, J. Korsmeyer S: BCL-2 family members and the mitochondria in apoptosis. Genes Dev 1999, 13:1899-1911.

18. Kim R, Tanabe K, Uchida Y, Emi M, Inoue H, Toge T: Current status of the molecular mechanisms of anticancer druginduced apoptosis. The contribution of molecular-level analysis to cancer chemotherapy. Cancer Chemoth Pharm 2002, 50:343-352.

19. Bhouri W, Derbel S, Skandrani I, Boubaker J, Bouhlel I, Ben Sghair M, Kilani S, Mariotte AM, Dijoux Franca MG, Ghedira K, Chekir Ghedira L: Study of genotoxic, antigenotoxic and antioxidant activities of the digallic acid isolated from Pistacia lentiscus fruits. Toxicol in vitro 2010, 24:509-515.

20. Polydoro M, De Souza KCB, Andrades ME, Da Silva EG, Bonatto F, Heydrich J, Dal-Pizzol F, Schapoval EES, Bassani VL, Moreira JCF: Antioxidant, a prooxidant and cytotoxic effects of Achyrocline satureioides extracts Brazil. Life Sci. 2004, 74:2815-2826.

21. Uliasz TF, Hewett SJA: microtiter trypan blue absorbance assay for the quantitative determination of excitotoxic neuronal injury in cell culture. $J$ Neurosci Methods 2000, 100:157-163.

22. Wang $C C$, Chen $L G$,Yang LL: Cytotoxic activity of sesquiterpenoids from Atractylodes ovata on leukaemia cell lines. Planta Med 2002, 68:204-208.

23. Martin SJ, Green DR: Protease activation during apoptosis. Cell 1995, 82:349-352.

24. Kucuk O: Cancer chemoprevention. Cancer Metastasis Review 2002, 21:189-197.

25. Weisburger JH: Practical approaches to chemoprevention of cancer. Drug Metab Rev 1994, 26:253-260.

26. Yang CS, Landau JM, Huang MT, Newmark HL: Inhibition of carcinogenesis by dietary polyphenolic compounds. Annu Rev Nutr 2001, 21:381-406.

27. Kurata R, Adachi M, Yamakawa O, Yoshimoto M: Growth suppression of human cancer cells by polyphenolics from sweetpotato (Ipomoea batatas L.) leaves. J Agr Food Chem 2007, 55:185-190.

28. Hu YW, Liu CY, Du CM, Zhang J, Wu WQ, Gu ZL: Induction of apoptosis in human hepatocarcinoma SMMC-7721 cells in vitro by flavonoids from Astragalus complanatus. J Ethnopharmacol 2009, 123:293-301.

29. Abdelwahed A, Bouhlel I, Skandrani I, Valenti K, Kadri M, Guiraud P, Steiman R, Mariotte AM, Ghedira K, Laporte F, Dijoux-Franca MG, Chekir-Ghedira L: Study of antimutagenic and antioxidant activities of Gallic acid and1,2,3,4,6-pentagalloylglucose from Pistacia lentiscus Confirmation by microarray expression profiling. Chemico biol interact. 2007, 165:1-13.

30. Isuzugawa $\mathrm{K}$, Inoue M, Ogihara $\mathrm{Y}$ : Catalase contents in cells determine sensitivity to the apoptosis inducer gallic acid. Biol Pharm Bull 2001, 24:1022-1026

31. Inoue M, Suzuki R, Sakaguchi N, Li Z, Takeda T, Ogihara Y, Jiang BY, Chen Y: Selective induction of cell death in cancer cells by gallic acid. Biol Pharm Bull 1995, 18:1526-1530.

32. Tewari M, Quan LT, O'Rourke $K$, Desnoyers $\mathrm{S}$, Zeng Z, Beidler DR, Poirier GG, Salvesen GS, Dixit VM: Yama/CPP32 beta, a mammalian homolog of CED-3, is a CrmA-inhibitable protease that cleaves the death substrate poly(ADP-ribose) polymerase. Cell 1995, 81:801-809.

33. Lazebnik YA, Kaufmann SH, Desnoyers S, Poirier GG, Earnshaw WC Cleavage of poly(ADP-ribose) polymerase by a proteinase with properties like ICE. Nature 1994, 371:346-347.

34. Nicholson DW, Ali A, Thornberry NA, Vaillancourt JP, Ding CK, Gallant M, Gareau Y, Griffin PR, Labelle M, Lazebnik YA, Munday NA, Raju SA, Smulson ME, Yamin TT, Yu VL, Miller DK: Identification and inhibition of the ICE/CED-3 protease necessary for mammalian apoptosis. Nature 1995, 376:37-43.

35. Degterev A, Boyce M, Yuan J: A decade of caspases. Oncogene 2003, 22:8543-8567.

36. Chen YC, Liang YC, Lin-Shiau SY, Ho CY, Lin JK: Inhibition of TPA-induced PKC and AP-1 binding activities by Theaflavin-3,3X-digallate from black tea in NIH3T3 cells. J Agricul and Food Chem 1999, 367:379-388. 
37. Liang YC, Chen YC, Lin YL, Lin-Shiau SY, Ho CT, Lin JK: Suppression of extracellular signals and cell proliferation by the black tea polyphenol, theaflavin-3,3X-digallate. Carcinogenesis 1999, 20:733-736.

38. Pan MH, Lin JH, Lin-Shiau SY, Lin JK: Induction of apoptosis by penta-O-galloyl-b-D-glucose through activation of caspase-3 in human leukemia HL-60 cells. Eur J Pharmacol 1999, 381:171-183.

39. Haslam E: Natural polyphenols (vegetable tannins) as drugs: possible modes of action. J Nat Prod 1996, 59:205-215.

40. Sakagami H, Kuribayashi N, lida M, Sakagami T, Takeda M, Fukuchi K, Gomi K, Ohata H, Momose K, Kawazoe Y, Hatano T, Yoshida T, Okuda T: Induction of DNA fragmentation by tannin- and Lignin-related substances. Cancer Res 1995, 15:2121-2128.

doi:10.1186/1475-2867-12-26

Cite this article as: Bhouri et al:: Investigation of the apoptotic way

induced by digallic acid in human lymphoblastoid TK6 cells. Cancer Cell International 2012 12:26.

\section{Submit your next manuscript to BioMed Central and take full advantage of:}

- Convenient online submission

- Thorough peer review

- No space constraints or color figure charges

- Immediate publication on acceptance

- Inclusion in PubMed, CAS, Scopus and Google Scholar

- Research which is freely available for redistribution 